\title{
The role of Lipoxin $A_{4}$ in endometrial biology and endometriosis
}

\author{
GO Canny ${ }^{1}$ and BA Lessey ${ }^{2}$
}

Lipoxin $\mathrm{A}_{4}\left(\mathrm{LXA}_{4}\right)$, an endogenous anti-inflammatory and immunomodulatory mediator studied in many disease states, is recently appreciated as a potentially significant player in the endometrium. This eicosanoid, synthesized from arachidonic acid via the action of lipoxygenase enzymes, is likely regulated in endometrial tissue during the menstrual cycle. Recent studies revealed that $\mathrm{LXA}_{4}$ acts as an estrogen receptor agonist in endometrial epithelial cells, antagonizing some estrogen-mediated activities in a manner similar to the weak estrogen estriol, with which it shares structural similarity. $\mathrm{LXA}_{4}$ may also be an anti-inflammatory molecule in the endometrium, though its precise function in various physiological and pathological scenarios remains to be determined. The expression patterns for $\mathrm{LXA}_{4}$ and its receptor in the female reproductive tract suggest a role in pregnancy. The present review provides an oversight of its known and putative roles in the context of immuno-endocrine crosstalk. Endometriosis, a common inflammatory condition and a major cause of infertility and pain, is currently treated by surgery or anti-hormone therapies that are contraceptive and associated with undesirable side effects. $\mathrm{LXA}_{4}$ may represent a potential therapeutic and further research to elucidate its function in endometrial tissue and the peritoneal cavity will undoubtedly provide valuable insights.

\section{INTRODUCTION}

The female reproductive tract maintains an immune surveillance system similar to other mucosal surfaces, serving as the front line against pathogens. The uterus is unique given its roles in the transport of male gametes and processing of seminal antigens. Immune crosstalk appears vital to the success of pregnancy and for tolerance of the fetal semi-allograft during implantation and throughout gestation. ${ }^{1}$ In addition, in menstruating species such as humans and most primates, the cyclic shedding of the upper two-thirds of the endometrial surface requires rapid healing and regeneration while maintaining those defenses and minimizing inflammatory responses. ${ }^{2}$

Ovulation, menstruation, implantation, and parturition all represent short-term inflammatory events ${ }^{3}$ limited by endogenous mediators that facilitate resolution of inflammation. Health is maintained by the balance between inflammation and metabolic and immune homeostasis, especially important at mucosal surfaces such as the female reproductive tract. A disequilibrium in the inflammatory response to disease underlies many immune-mediated illnesses. ${ }^{4-8}$ Lipoxins (LXs), as well as the more recently discovered Resolvins and Protectins, are specialized pro-resolving mediators essential for the resolution of inflammation ${ }^{9}$ In this review, we focus on a molecule likely central to this balancing act in endometrial tissue, Lipoxin $\mathrm{A}_{4}\left(\mathrm{LXA}_{4}\right)$.

$\mathrm{LXA}_{4}$ has been implicated as an anti-inflammatory mediator in human cycling endometrium and following parturition. ${ }^{10,11}$ The significance of $\mathrm{LXA}_{4}$ in normal endometrial physiology is difficult to gauge given the complexities of its signaling via different receptors with varying roles in multiple cell types as well as the paucity of published data concerning its function (Figure 1). As an immune modulator, $\mathrm{LXA}_{4}$ has been shown in other systems to inhibit leukocyte migration, ${ }^{12}$ leukotrieneinduced responses, including vasoconstriction and chemotactic responses, ${ }^{13,14}$ and mitogenic signals. ${ }^{15}$ Based on recent studies, $\mathrm{LXA}_{4}$ and related mediators are likely to contribute to endometrial biology serving as a fulcrum between opposing forces to help maintain the balance required for tissue repair/ wound healing during menstruation, tolerance toward the nascent embryonic fetal allograft, maintenance of pregnancy, and the initiation and resolution of parturition. Additionally, as attenuated $\mathrm{LXA}_{4}$ production may contribute directly to many inflammatory conditions and chronic disease states, ${ }^{16-20}$

${ }^{1}$ Geneva Foundation for Medical Education and Research, Versoix, Switzerland and ${ }^{2}$ University of South Carolina School of Medicine—Greenville, Greenville, SC, USA. Correspondence: GO Canny (Geraldine.Canny@gmail.com)

Received 4 July 2012; accepted 16 January 2013; published online 13 March 2013. doi:10.1038/mi.2013.9 
dysregulation of $\mathrm{LXA}_{4}$ actions may significantly impact endometrial health and reproductive function.

\section{LIPOXIN $\mathrm{A}_{4}$ BIOSYNTHESIS AND LIPOXYGENASE METABOLITES}

In humans, the major LX biosynthetic pathways involve biosynthesis during specific cell:cell interactions and upon priming by cytokines ${ }^{21,22}$ in the vasculature and at mucosal boundaries, such as the endometrium. LX production occurs in a transcellular manner at sites of inflammation involving two different cell types such as epithelial cells and neutrophils, for example. Three human lipoxygenase (LOX) enzymes, ironcontaining enzymes that catalyze the hydroperoxidation of polyunsaturated fatty acids, have been cloned: 5-LOX, 12-LOX, and 15-LOX. ${ }^{23,24}$ The sequential oxygenation of arachidonic acid results in LX formation. Aspirin triggers the generation of epimeric forms of LXs known as aspirin-triggered LXs, such as 15 -epi-LXA ${ }_{4}{ }^{25}$ an attribute also shared by statins. ${ }^{26,27} 15$ ALOX type 2, which exhibits a substrate preference for arachidonic acid converting it to 15S-hydroperoxyeicosatetraenoic acid (15S-HETE), ${ }^{24}$ is expressed in human endometrium. ${ }^{28}$ However, human 15-LOX isoforms exhibit allosteric product regulation, ${ }^{29}$ and the functional significance of feedback loops in vivo merits further investigation.

Interleukin 13 (IL-13), is a potent inducer of 15-LOX gene expression and enzyme activity in human monocytes, ${ }^{30}$ requiring ERK1/2 MAPK (extracellular signal-regulated kinase $1 / 2 /$ mitogen-activated protein kinase) activation. ${ }^{31}$ IL-13 was also shown to induce the mouse homolog $12 / 15$-LOX in monocytes while IFN- $\gamma$ (interferon gamma) inhibited expression and activity of this enzyme. IL-4 also induced 12/15-LOX in mouse myeloid cells. ${ }^{32}$ Both IL-4 and IL-13 are involved in differentiation of monocytes into M2 macrophages, which exhibit an immunosuppressive phenotype when compared with M1 macrophages. ${ }^{33}$

$12 / 15-\mathrm{LOX}$ is a progesterone target gene in the mouse uterus, based on the progesterone receptor knockout mouse model. ${ }^{34}$ There is precedent for hormonal regulation of this enzyme in mucosal tissues, such as the cornea, where $17 \beta$-estradiol (E2) downregulates 15 -LOX as well as $\mathrm{LXA}_{4}$ formation. ${ }^{35}$ In prostate cancer cells, glucocorticoids inhibit this enzyme, ${ }^{36}$ and in vascular smooth muscle cells aldosterone stimulates 12/15LOX expression. ${ }^{37}$ In prostate epithelial cells, peroxisome proliferator-activated receptor-gamma (PPAR- $\gamma$ ) interacts with the orphan receptor ROR- $\alpha$ to bind the 15 -LOX promoter, providing a novel negative feedback mechanism for 15-LOX and therefore $\mathrm{LXA}_{4}$ production. ${ }^{38}$ It remains to be seen whether such regulatory mechanisms are germane to the human endometrium.

$\mathrm{LXA}_{4}$ levels are high at the end of the menstrual cycle and then decline after menses. ${ }^{10}$ That is, coincidently, the time when IL-13 peaks during the normal menstrual cycle. ${ }^{39}$ As previously noted, estrogen-mediated inhibition of this enzyme ${ }^{35}$ would fit well with the observation that $\mathrm{LXA}_{4}$ levels decline during the proliferative phase coincident with a rise in $\mathrm{E} 2 .{ }^{10}$ The increase in $\mathrm{LXA}_{4}$ levels during pregnancy is likely due to human chorionic gonadotropin, which promotes $\mathrm{LXA}_{4}$ release in the decidua of human endometrium. ${ }^{10}$

LOX metabolites have been implicated in reproductive function for over three decades. One study in mice provided direct evidence of the importance of LOX metabolites during implantation. ${ }^{34}$ Using conditional PR knockout mice it was established that leukocyte and epidermal 12/15-LOX were downstream targets of PR in uterine surface epithelium. At implantation, maximal induction of both 12/15-LOX enzymes was observed, with a parallel increase in the eicosanoid metabolites 12-HETE, 15-HETE, and 13-HODE (13-(S)hydroxyoctadecadienoic acid) in the uterus. Furthermore, leukocyte 12/15-LOX null mice exhibited impaired implantation and usage of a 12/15-LOX inhibitor confirmed these results, leading to a significant reduction in implantation sites. 12-HETE, 15-HETE, and 13-HODE activated PPAR- $\gamma$ in cellbased assays, and Rosiglitazone, a PPAR- $\gamma$ agonist, reversed the ability of a LOX inhibitor to inhibit implantation. This was the first demonstration that progesterone-induced synthesis of lipid mediators derived from 12/15-LOX activity activated PPAR- $\gamma$ and associated signaling pathways, serving to regulate implantation in the mouse. Indeed, LOX inhibitors have been shown to indirectly reduce progesterone output in pregnancy. ${ }^{40}$ It will be instructive to determine the relative roles of these intermediate metabolites and whether $\mathrm{LXA}_{4}$ is also involved.

\section{LXA $_{4}$ RECEPTORS}

Of the LX family members, $\mathrm{LXA}_{4}$ is the best characterized. $\mathrm{LXA}_{4}$ inhibits immune cell recruitment, chemotaxis, adhesion, and transmigration, also attenuating pro-inflammatory cytokine production and promoting resolution of inflammation, thereby serving as an important brake after injury or cellular insult in vitro and in vivo. $\mathrm{LXA}_{4}$ modulates the function of both myeloid and non-myeloid cell types. ${ }^{41,42}$ This anti-inflammatory mediator appears promiscuous in its ability to bind and/or activate a number of both nuclear as well as membrane-bound receptors. $\mathrm{LXA}_{4}$ directly or indirectly activates various receptors, including a subclass of peptide receptors (CysLTs (cysteinyl leukotrienes)), ${ }^{15}$ as well as the G-protein-coupled receptor $32 .{ }^{43} \mathrm{LXA}_{4}$ receptors also include formyl peptide receptor 2/LX $\mathrm{A}_{4}$ receptor (FPR2/ALX), another surface membrane G-protein-coupled receptor with diverse ligands, ${ }^{44,45}$ the aryl hydrocarbon receptor (AhR), a ligandactivated nuclear transcription factor, ${ }^{46}$ and more recently, estrogen receptor-alpha $(\mathrm{ER} \alpha) \cdot{ }^{28}$ Expression dynamics of the latter three receptors and $\mathrm{LXA}_{4}$ itself in endometrial tissue are depicted in Figure 2.

FPR2/ALX, the most studied receptor, to which $\mathrm{LXA}_{4}$ binds with high affinity, ${ }^{44,45}$ is expressed by many different cell types, including neutrophils, monocytes, natural killer cells as well as epithelial cells, where its expression is subject to differential regulation by cytokines. ${ }^{23,47}$ A recent study on the molecular regulation of FPR2/ALX reported that although monocytes expressed this receptor, their differentiation abrogated its expression, due to translation silencing. ${ }^{48}$ These results suggest that FPR2/ALX is of limited relevance in tissue macrophage 


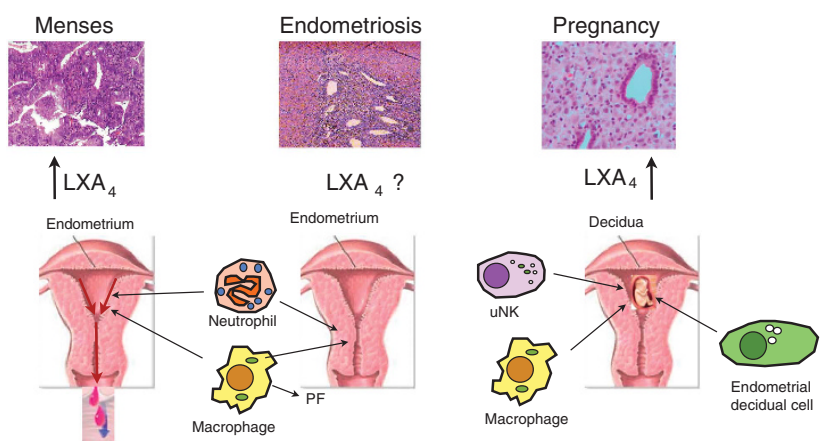

Figure 1 Lipoxin $\mathrm{A}_{4}\left(\mathrm{LXA}_{4}\right)$-mediated actions in the endometrium at menses and in pregnancy on epithelial and stromal cells as well as on various immune cells of the innate arm. During menses, neutrophils and other immune cells are recruited just before menstruation and are normally cleared with debris, likely by macrophage-mediated efferocytosis, as a new endometrial layer forms. $\mathrm{LXA}_{4}$ is produced via transcellular biosynthesis and 15-lipoxygenase is regulated by progesterone. In pregnancy, $\mathrm{LXA}_{4}$ and its receptor appear to be upregulated, especially in the decidua, a putative function of $\mathrm{LXA}_{4}$ in this environment would be to modulate macrophage activity and tissue remodeling. Elevated serum levels during gestation may fulfill immunomodulatory roles. In endometriosis (middle panel), characterized by excessive estrogen production and progesterone resistance, $\mathrm{LXA}_{4}$ levels have not been studied. In this setting, $\mathrm{LXA}_{4}$ biosynthesis is possibly decreased leading to a defect in the resolution of inflammation or alternatively, due to the inflammatory nature of this condition, may be overexpressed. The functional significance of $\mathrm{LXA}_{4}$ in eutopic and ectopic endometrial tissue, as well as in the peritoneal fluid (PF), remains to be clarified. uNK, uterine natural killer cell.

function, but further studies are required to delineate the functional significance of this observation. Recently, expression of FPR2/ALX in human endometrium has been described. ${ }^{10}$ MacDonald et al. $^{10}$ found that FPR2/ALX mRNA expression is increased during the menstrual phase compared with proliferative, early- and mid-secretory phase endometrium. As the endometrium has an upper (zona functionalis) and lower regenerative layer (zona basalis), FPR2/ALX receptor localization was found to be highest in the functionalis layer, localized to glandular epithelial and stromal cells, as well as the cells lining the vasculature and associated immune cells. We observed a smiliar expression pattern (G. Canny, unpublished data). In the first trimester of pregnancy, the decidua also exhibits high FPR2/ALX expression. Although $\mathrm{LXA}_{4}$ levels did not change in the peripheral circulation across the menstrual cycle, serum levels were increased during early pregnancy, coincident with elevated FPR2/ALX levels.

Another physiologically relevant receptor for $\mathrm{LXA}_{4}$ is $\mathrm{AhR}$, which $\mathrm{LXA}_{4}$ was shown to activate in murine hepatoma cells ${ }^{46}$ and murine dendritic cells. ${ }^{49}$ Interestingly, AhR has a role in immunity, with AhR-regulated genes being modulated by environmental toxins and pro-inflammatory cytokines. ${ }^{50,51}$ AhR-null mice succumb significantly faster to experimental toxoplasmosis than wild-type mice and displayed greater degrees of liver damage as well as augmented serum levels of tumor necrosis factor-alpha (TNF- $\alpha$ ), nitric oxide, and IgE but lower IL-10 production. ${ }^{52}$ Hematopoietic defects are also
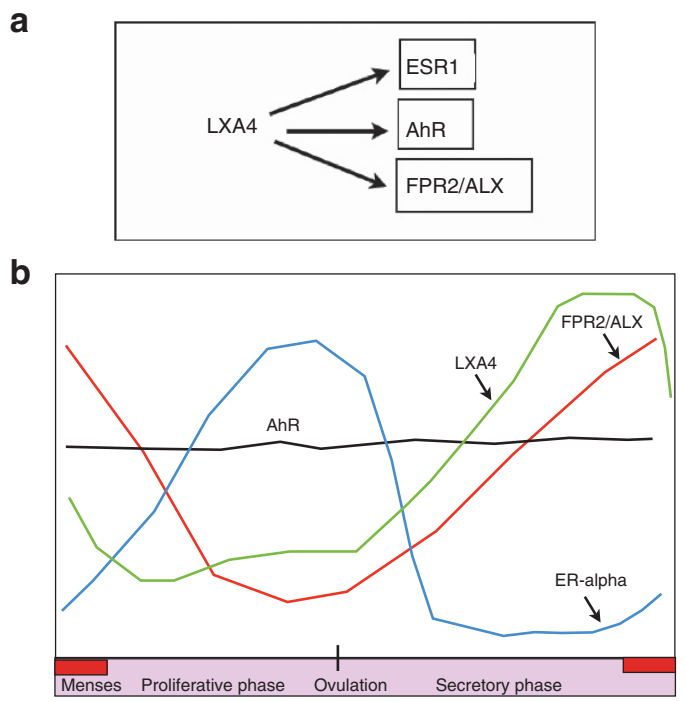

C

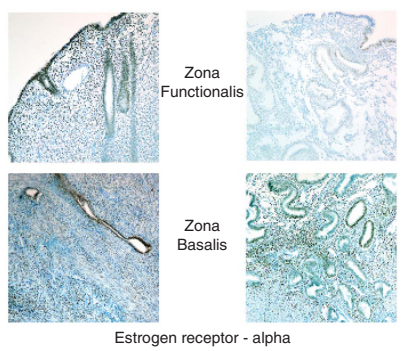

Figure 2 Serum $\mathrm{LXA}_{4}$ levels and receptor expression dynamics in endometrial tissue. (a) Lipoxin $\mathrm{A}_{4}\left(\mathrm{LXA}_{4}\right)$ activates multiple receptors and has been shown to bind three present in the endometrium; formyl peptide receptor 2/lipoxin $\mathrm{A}_{4}$ receptor (FPR2/ALX), a G-protein-coupled receptor, aryl hydrocarbon receptor (AhR), a nuclear receptor, and estrogen receptor-alpha (ESR1), which can exist in nuclear and membranous forms. (b) Each receptor appears to be differentially regulated, with FPR2/ ALX expressed with similar temporal dynamics to $L X A_{4}$. Serum LXA levels have been reported (depicted by a green line), but no data describing endometrial tissue levels have been published. $L X A_{4}$ also binds to estrogen receptor-alpha (ESR1), which increases in the proliferative phase in response to estrogen and later falls due to progesterone. AhR is constitutively expressed throughout the menstrual cycle, but its functional significance is unclear. (c) Immunohistochemical analyses of ESR1 expression during the secretory phase of the menstrual cycle in both the zona functionalis (left upper panel) as well as the zona basalis (left lower panel). ESR1 is downregulated in the functionalis layer (right upper panel) but maintained in the zona basalis (right lower panel). At menses, when estradiol levels are at their nadir, LXA ${ }_{4}$ could target the nascent endometrial epithelium and stroma through ESR1 to promote early proliferation and repair. Studies on both humans and primates have provided evidence for cell division in this layer, despite the low endogenous estrogen levels. Thus, $\mathrm{LXA}_{4}$ may serve as an early signal for endometrial regeneration and renewal.

observed in $\mathrm{AhR}^{-1-}$ mice and, though classically considered important in mediating responses to environmental toxins, AhR is increasingly thought to be involved in immune responses. ${ }^{53}$ Of note, cyclo-oxygenase 2 (COX-2), the rate limiting enzyme in prostaglandin $\mathrm{E}_{2}\left(\mathrm{PGE}_{2}\right)$ production is inducible by AhR ligands in various cell types. ${ }^{50}$ Although AhR is present in the human endometrium, where its expression remained constant across the menstrual cycle, ${ }^{54}$ there have so 
far been no confirmatory reports demonstrating AhR activation by $\mathrm{LXA}_{4}$ in this tissue.

$\mathrm{LXA}_{4}$ was recently characterized as an ER ligand, stimulating expression of estrogen responsive genes, including alkaline phosphatase and $\mathrm{PR}$, and inducing proliferation in human endometrial epithelial cells. ${ }^{28}$ Interestingly, $\mathrm{LXA}_{4}$ shares a high degree of structural similarity with the weak estrogen estriol (E3) made in large amounts by the placenta during pregnancy. ${ }^{55,56}$ Consistent with the characteristics of a weak ER $\alpha$ agonist, $\mathrm{LXA}_{4}$ also inhibited E2-mediated actions, as was previously shown for $\mathrm{E}^{57}$ and competed directly for $\mathrm{ER}$ binding with an $\mathrm{IC}_{50}$ of $46 \mathrm{~nm}$. Arachidonic acid and 15S-HETE, the LX precursors, as well as $\mathrm{LXB}_{4}$, an isomer, displayed minimal or no binding affinity, confirming the structural specificity. Acting in a manner similar to canonical ER signaling, ${ }^{58} \mathrm{LXA}_{4}$ induced $\mathrm{ER} \alpha$ phosphorylation and targeted this receptor for degradation by the proteasome. Further confirmatory studies in mice revealed that $\mathrm{LXA}_{4}$ stimulated a uterotrophic response and induced estrogen-responsive genes, including PR in uterine tissue in vivo.

It should be noted that all the three above-mentioned receptors are promiscuous and subject to complex regulation in the different endometrial cell types and at different stages of the menstrual cycle or during gestation. Since multiple receptors may be present in the same cell, well-controlled studies are needed to fully explore potential crosstalk between these different classes of receptors and associated signaling systems, using physiologically relevant ligand concentrations and readouts.

\section{ALTERNATIVE VIEWS ON LXA ${ }_{4}$ AND ESTROGEN ACTION}

The endometrium is a steroid hormone-dependent tissue and, in the humans, undergoes cyclic changes in response to the sequential actions of estrogen and progesterone. ${ }^{59}$ Although the steroid hormone and gene regulation patterns of the normal menstrual cycle are beyond the scope of this review, endometrial changes have now been well characterized in both health and disease. ${ }^{60-65}$ One of the major factors in endometrial-related diseases is the imbalance between the actions of estrogen and progesterone. Aside from the obvious example of endometrial cancer, endometriosis is a major health problem in women of reproductive age. The pathophysiology of endometriosis is intimately linked with inflammation, a resistance to progesterone, exaggerated estrogen responsiveness, and/or increased ER signaling. ${ }^{66}$

Estrogen action in the endometrium in both health and disease is an active area of research, and both estradiol and progesterone regulate the inflammatory events during menstruation and implantation. ${ }^{62,67}$ It has long been known that estrogen upregulates both $\mathrm{ER} \alpha$ and PR in the human endometrium $^{68,69}$ as well as in primates and other mammals. ${ }^{70}$ Likewise, these studies have shown that progesterone downregulates both ER $\alpha$ and PR during the secretory phase of the cycle. $^{71}$ Early ER $\alpha$ immunohistochemistry data in human endometrium show that there is a marked reduction in all the cell types during the mid-secretory phase. ${ }^{72-75}$ ER downregulated in luminal and glandular epithelium was associated with a decline in cell proliferation, except in the zona basalis. ${ }^{76,77}$ In pregnancy, ER $\alpha$ is essentially absent due to its down-modulation by progesterone. ${ }^{78-82}$ Interestingly, the timely loss of epithelial PR in the endometrium closely correlates well with the establishment of uterine receptivity in humans as well as in most mammals studied. ${ }^{81,83-88} \mathrm{~A}$ delay in the opening of the window of implantation is associated with a correctable delay in the down-modulation of epithelial PR. ${ }^{89}$ It has been suggested that E2 is unnecessary for normal endometrial secretory development. ${ }^{90}$ Failure of ER $\alpha$ downregulation could therefore, be an indirect sign of progesterone resistance and has been reported in endometrial hyperplasia, ${ }^{75}$ endometriosis, ${ }^{91-95}$ and in the endometrium of women with polycystic ovary syndrome. ${ }^{64}$ Together, these data support the association between aberrant proliferation and the dysregulation of progesterone action, leading to proliferative disorders of the endometrium and a lack of uterine receptivity.

The interactions between eicosanoids, lipoxygenase metabolites, estrogens and nuclear receptors have not been well studied. E2 is the most potent estrogen produced in the body and like other estrogens exerts its physiological actions though binding to and translocation of their receptors. ERs belong to the nuclear hormone receptor superfamily and function as ligand-activated transcription factors. ${ }^{96}$ Estrogen signaling is largely mediated through two receptor isoforms: $\mathrm{ER} \alpha$ and $\mathrm{ER} \beta$, initiating both genomic and non-genomic effects. ${ }^{97}$ Both of these ERs are abundant in reproductive tissues, ER $\alpha$ being the dominant receptor within the adult uterus ${ }^{98}$ and ER $\beta$ of greater concentration in vascular cells or of interest in reproductive tissues. ${ }^{74,99,100}$ Membrane ERs also exist, including the newly discovered G-protein-coupled receptor-30, recently studied in the endometrium. ${ }^{101}$ Although studies using ER $\alpha$-deficient mice have revealed the central role of this receptor in reproductive function at all levels of the hypothalamicpituitary-gonadal axis, ${ }^{102}$ ER $\beta$-mutant mice exhibit normal puberty but reduced fecundity due to an impaired ovulation rate. ${ }^{103}$ G-protein-coupled receptor 30 is dispensable for fertility and does not mediate estrogenic responses in mouse reproductive organs. ${ }^{104}$

In addition to ligand-induced activation, ERs are also subject to phosphorylation by various kinases that are themselves activated by inflammatory mediators or cytokines during endometrial remodeling. ${ }^{105}$ TNF $\alpha$ was recently shown to activate ER and induce E2-regulated genes in endometrial epithelial cells, ${ }^{106}$ indicating immunoendocrine crosstalk occurs in inflammatory endometrial conditions. The significance of membrane-initiated steroid signaling ${ }^{107}$ in these contexts remains to be elucidated, but alternations in the inflammatory milieu could dramatically alter the actions of estrogens, their metabolites, or other ligands, such as $\mathrm{LXA}_{4}$.

A model of $\mathrm{LXA}_{4}$-mediated actions in endometrial tissue would depend on temporal and spatial availability of available ligands and receptors (Figure 2). The increased level of FPR2/ ALX at menses, ${ }^{10}$ potentially coinciding with increased local $\mathrm{LXA}_{4}$ production due to immunocyte influx, ${ }^{108}$ could 
contribute to the early burst of endometrial healing and growth that occur at a time when endogenous E2 is relatively low. In addition, higher $\mathrm{ER} \alpha$ expression noted in the basalis glands and stroma provides a potential target for $\mathrm{LXA}_{4}$ at menses when estrogen levels are at their nadir. Whether $\mathrm{LXA}_{4}$ initiates endometrial regeneration and healing at this time merits investigation.

The zona basalis in primates undergoes cellular proliferation in the mid-to-late secretory phase. ${ }^{76,77}$ Given the reduced level of estrogen in the secretory phase and the virtual absence of ER $\alpha$ in endometrial epithelium and stroma of the zona functionalis at the time of implantation, ${ }^{73,74}$ it is possible that $\mathrm{LXA}_{4}$ has a role in that early proliferative activity seen in the basal glands, thought to be an important aspect of endometrial regeneration. $\mathrm{ER} \beta$, on the other hand, present in vascular components of the endometrium and placenta ${ }^{109}$ or FPR2/ALX, present in the decidualized stroma, immune cells in the vasculature, and in the myometrium of human uterus, ${ }^{10}$ may also be targets for $\mathrm{LXA}_{4}$ exerting anti-inflammatory actions to support the ongoing pregnancy (Figure 1). Pregnancy is, by necessity, an immunocompromised state, whereby the growing fetus is tolerated while maintaining maternal immunity. ${ }^{10} \mathrm{LXA}_{4}$, acting as an $\mathrm{ER} \alpha$ agonist as previously observed in human endometrial epithelial cells, ${ }^{28}$ may participate in the downregulation of $\mathrm{ER} \alpha$ observed in the late secretory phase. Loss of $\mathrm{ER} \alpha$ is also essential in the pre-implantation uterus of most mammalian species.

Finally, AhR is a known receptor for $\mathrm{LXA}_{4}$ and is present in the endometrium of secretory endometrium. ${ }^{54}$ Considering the putative role of $A h R$ as a suppressor of $E R \alpha$ signaling via several mechanisms, ${ }^{11,112}$ it could be speculated that $\mathrm{LXA}_{4}$ might come into play in certain circumstances. Although we showed that AhR does not seem to be involved in $\mathrm{LXA}_{4}$ signaling in human endometrial epithelial cells, ${ }^{28}$ actions involving this receptor in other cell types under different circumstances or in vivo cannot be excluded.

\section{MACROPHAGES AS A LXA TARGET $_{4}$}

Innate immune cells, including macrophages are a major target of $\mathrm{LXA}_{4}$-mediated bioactivities (Figure 1). Given that leukocytes represent $30-40 \%$ of the endometrial cell population ${ }^{113}$ leading to $\mathrm{LXA}_{4}$ transcellular biosynthesis, this lipid mediator likely has a role in homeostatic processes. Macrophages and uterine natural killer cells are abundant in the endometrial stroma and are found through most of the menstrual cycle. Sex hormones regulate macrophage distribution in this tissue. Macrophage numbers increase in the premenstrual endometrial stroma, coinciding with falling estrogen and progesterone levels due to the demise of the corpus luteum. ${ }^{114}$

Macrophages, through their ability to produce matrix metalloproteinases (MMPs), are involved in tissue remodeling and are intimately linked with both menstruation ${ }^{108,113,115}$ and pregnancy. ${ }^{116,117}$ It is noteworthy that $\mathrm{LXA}_{4}$ and its analogs decrease MMP expression and activity in many different cell types ${ }^{118,119}$ and also in peritoneal fluid cells in a mouse model of endometriosis, ${ }^{120,121}$ of which macrophages comprise a major component.

In the first trimester of pregnancy, macrophages constitute the second most predominant leukocyte population $(<30 \%)$ of decidual cells after decidual natural killer cells $(<70 \%)^{122}$ and differentiate from monocytes. Decidual macrophages function in the removal of apoptotic bodies, uterine vascular remodeling, immune tolerance towards fetal antigens, immunity against external pathogens and cervical ripening and recovery ${ }^{123}$ and elicit immunosuppressive and anti-inflammatory responses. Apoptotic body clearance results in the expression of antiinflammatory cytokines such as IL-4, IL-6, and IL-10, with protective effects on trophoblast survival. Efferocytosis is a process whereby phagocytes engulf apoptotic cells and the latter impact macrophage phenotype. The newly discovered proresolving macrophage subset, Mres, appear later in the resolution program. ${ }^{124} \mathrm{LXA}_{4}$ promotes the engulfment of apoptotic neutrophils, and tissue fragments, by macrophages, a process essential to the resolution of inflammation ${ }^{125,126}$ and the re-establishment of tissue integrity post-menstruation. ${ }^{113}$

The domains of immunology and metabolism are converging, providing insights into a variety of physiological and pathological states. ${ }^{127}$ The previously mentioned ALOX metabolites and PPAR ligands, as well as T helper type 2 (Th2) cytokines and specialized pro-resolution mediators drive temporarily distinct metabolic shifts and effector functions in macrophages. ${ }^{128}$ Recent studies have implicated ER $\alpha$ in macrophage function and metabolism and demonstrated a protective role for this receptor on hematopoetic/myeloid cells in atherosclerosis-related inflammation. ${ }^{129}$ As alluded to above, estrogens are linked with macrophage recruitment into the endometrium and are clearly implicated in immune responses. The role of $\mathrm{ER} \alpha$ in $\mathrm{LXA}_{4}$-mediated regulation of macrophage function in the endometrium and peritoneal cavity awaits elucidation.

\section{ENDOMETRIOSIS: A COMPLEX DISEASE FOR WHICH IMPROVED TREATMENT MODALITIES ARE NECESSARY}

Endometriosis, an inflammatory, estrogen-stimulated disease affects approximately $10 \%$ of women of reproductive age, and it is estimated that up to $80 \%$ of unexplained infertility is attributable to this condition. ${ }^{65,130,131}$ First described by Daniel Schroen in 1690, several theories have been proposed but none fully explain the etiology. The most well accepted is Sampson's ${ }^{132}$ theory of retrograde menstruation, whereby fragments of menstrual endometrium pass backward through the fallopian tubes and into the peritoneal cavity where they implant and persist. The eutopic endometrium of women with endometriosis becomes altered as shown in the baboon model, ${ }^{133,134}$ with increased estrogen activity, cellular proliferation, and progesterone resistance. ${ }^{66}$ The biological mechanisms linking endometriotic lesions to these endometrial alterations remains uncertain and controversial. ${ }^{135}$ Although progesterone resistance and estrogen dominance likely contribute to the pathophysiology and survival of ectopic 
lesions, ${ }^{134,136,137}$ they probably contribute to infertility as well. $^{66,95,134}$ There is overwhelming evidence that normal immune responses, which serve to promote fertility and immunotolerance, are altered in women with endometriosis, with inflammatory changes in the intrauterine milieu, the peritoneal cavity, and systemic circulation. ${ }^{65,138-140}$

Cellular proliferation and inflammation are intimately linked via both hormonal and inflammatory mediators such as IL-1, TNF- $\alpha, \mathrm{PGE}_{2}$, or E2, which, in turn, induce growth factors, cytokines, and chemokines that promote inflammation, cellular proliferation, and angio- and lymphangiogenesis. ${ }^{141,142}$ Estrogens directly regulate the endometrial expression of many cytokines and growth factors as well as their receptors thereby contributing to endometriotic lesion growth. ${ }^{140}$ Conversely, TNF- $\alpha$ increases estrogen biosynthesis by human endometrial glandular cells and directs estrogen metabolism towards more hormonally active and carcinogenic metabolites. ${ }^{143}$ Crosstalk between the immune and endocrine systems therefore clearly contributes to endometriosis pathology.

Dysregulations in local immune mediator concentration and/or signaling leads to increased inflammation in the peritoneal cavity and the resulting systemic changes could conceivably alter the number and profile of immune cells that traffic to the endometrium. Dysfunction in macrophagemediated phagocytosis of cells that are transported into the peritoneal cavity by retrograde menstruation is considered an important factor in the development of endometriosis. $\mathrm{PGE}_{2}$ diminished human macrophage-mediated phagocytosis by downregulating the scavenger receptor and lipid transporter CD36, thought to have a significant role in macrophagemediated phagocytosis, and also increased endometriotic lesion size in mice. ${ }^{144}$ There is some evidence that macrophages in endometriosis are M2 polarized, also known as alternatively activated macrophages, in human, mouse, and primate. ${ }^{145,146}$ In the former study, macrophages in both inflammatory liquid and ectopic lesions were M2 polarized in endometriosis patients but not in control subjects. Adoptive transfer of alternatively activated macrophages dramatically enhanced endometriotic lesion growth in mice, and M1 polarized, inflammatory macrophages protected mice from disease establishment. It should be noted, however, that human macrophages markers are less well characterized than murine cells and extracellular marker analysis should ideally be coupled with that of pertinent effector molecules. Several different types of macrophages subsets have been described, and more are likely yet to be discovered. Macrophages display a phenotypic plasticity as a function of environmental cues, including cytokines and growth factors. ${ }^{33} \mathrm{LXA}_{4}$ promotes M2 polarization in vitro. ${ }^{147}$ Further studies are necessary to determine the precise macrophage subsets in endometrial tissue and peritoneal fluid and whether their polarization contributes to pathological responses.

In endometriosis, establishment of an immunotolerant (Th2/Treg (regulatory $\mathrm{T}$ cell)) environment ${ }^{139,148,149}$ appears to be replaced by an inflammatory Th1/Th17 immune response. $^{1,150}$ Retinoids, vitamin A derivatives that mediate diverse physiological functions, exert their pleiotropic effects through the interaction with nuclear receptors, defined as retinoic acid receptors and retinoid X receptors (RXRs). ${ }^{151}$ Retinoic acid (RA) as an important intermediary down-stream effector of progesterone action is also involved in immune cell programming. ${ }^{152}$ Retinol-binding proteins are under the regulation of progesterone in primates ${ }^{153}$ and human endometrium. Among six retinoid receptors examined, RXR $\gamma$ immunoreactivity was exclusively detected in the epithelial cells of the secretory phase endometrium but not of the proliferative phase. ${ }^{154}$ These data indicate that its expression is induced by progesterone. It is noteworthy that nuclear receptors such as RXR and PPAR- $\gamma$ heterodimerize and it seems that these dimers provide cells such as macrophages with a coordinated and inter-related network of transcriptional regulators for interpreting local metabolic changes resulting in subtype differentiation. ${ }^{152}$ T-cell differentiation is altered toward an inflammatory phenotype in endometriosis, RA and PPAR- $\gamma$ being essential for Treg differentiation. ${ }^{155,156}$ Inflammatory changes, including augmented IL- 6 and IL-23, promotes conversion of Tregs to Th17 cells. ${ }^{157}$ Of note, PPAR- $\gamma$ selectively inhibits Th17 differentiation of CD $4+$ T-cells. ${ }^{156}$ As such, several nuclear receptors likely impact physiological and pathological processes in endometrial tissue, conceivably involving $\mathrm{LXA}_{4}$.

$\mathrm{LXA}_{4}$ inhibits endometriosis progression in the mouse preclinical model. ${ }^{121,158}$ As shown for LXA $_{4}$ or a stable analog, ${ }^{121,159}$ pretreatment with a combination of progesterone, RA, and TGF $\beta$ greatly attenuates MMPs expression and reduces endometriotic lesion growth. ${ }^{160}$ Interestingly, $\mathrm{LXA}_{4}$ also suppresses phorbol myristate acetate-induced expression of the inflammatory cytokines IL- 6 and IL- 8 in human decidua tissue $^{10}$ and attenuates CCL2, IL-6 and inhibit nuclear factor (NF) $-\kappa B$ and Akt pathways in other animal models of inflammation. ${ }^{161,162}$ These observations may constitute mechanisms underlying its beneficial effects in preclinical endometriosis models but also raise the question whether $\mathrm{LXA}_{4}$ is a downstream effector of progesterone and RA actions. Interestingly, a recent paper demonstrated the protective effect of fish oil in endometriosis in a chimeric model where human endometrial tissue was injected into the peritoneum of nude mice. ${ }^{163}$ Mice administered fish oil exhibited fewer leukocytes within lesions and less collagen deposition at adhesions indicating that dietary intervention may prevent postsurgical adhesion development. These effects may well be due to the formation of pro-resolving lipid mediators such as resolvins and protectins, metabolized from omega 3 fatty acids. ${ }^{9}$

Hormone production, signaling, and metabolism are significantly perturbed and progesterone resistance comprises part of the pathology. ${ }^{66,164}$ Treatment of endometrial epithelial cells with 2,3,7,8-tetrachlorodibenzo-p-dioxin, a potent AhR ligand, altered the expression of $\mathrm{PR}-\mathrm{B}^{165}$ as a possible mechanism of progesterone resistance, this environmental toxin having been implicated in endometriosis development. PR-B in the uterus can exert an anti-inflammatory action, opposing PR-A. ${ }^{166}$ PR-A induced inflammatory cytokines 
IL-8-, IL-1 $\beta$-, and NF- $\kappa B$-regulated genes, while PR-B induced FKBP52 and NFKB1A, an inhibitor of the NF- $\kappa B$ pathway. FKBP52 has been shown to be decreased in endometriosis. ${ }^{167,168}$ This PR chaperone protein is required for proper progesterone-mediated actions and its reduction in this disease may be a major determinant in progesterone resistance. ${ }^{136}$

Progesterone resistance in endometriosis is associated with a decrease in RA activity; ${ }^{169}$ RA uptake protein STRA6 and cellular RA-binding protein 2 (both progesterone-regulated genes) are reduced in eutopic endometrium in endometriosis. Women with unexplained pregnancy loss also have reduced RA-binding protein $2 .{ }^{170} \mathrm{~A}$ recent study showed that RA treatment reduced endometriosis lesion size in the mouse model, with decreased IL- 6 and MCP- $1,{ }^{171}$ actions similar to those elicited by $\mathrm{LXA}_{4}$. RA acts in concert with progesterone and PPAR- $\gamma$ to limit inflammation; specifically inhibiting the expression of the pleiotrophic cytokine IL- 6 at the promoter, limiting its production ${ }^{172}$ along with IFN- $\gamma$, while reduced RA action results in augmented IL-6 expression. ${ }^{169}$ In endometriosis, stromal cells produce increased IL-6 in response to IL- $1 \beta{ }^{173}$

Estrogen's ability to inhibit $\mathrm{LXA}_{4}$ production in other mucosal tissues ${ }^{35}$ has important potential implications for endometriosis. As progesterone opposes estrogen action, progesterone resistance leads to increased estrogenicity in eutopic and ectopic endometrial tissue, perhaps also in the peritoneal compartment. ER $\alpha$ itself is one of the best recognized markers of progesterone resistance. In endometriosis, $\mathrm{ER} \alpha$ is more abundant and displays a failure of downregulation in eutopic ${ }^{95}$ and ectopic tissue. ${ }^{174,175}$ The underlying reasons are unknown but could include aberrant modification and/or targeting to the proteasome, as part of abnormal responses to this hormone, or could be linked to progesterone resistance. $\mathrm{ER} \alpha$ is more important than $\mathrm{ER} \beta$ in endometriosis lesion development in mice, as recently demonstrated in an immunocompetent model. ${ }^{176}$ In this study, ER $\alpha$-null lesions were associated with increased inflammation, it is therefore tempting to speculate that endogenous $\mathrm{ER} \alpha$ ligands mediate this effect.

However, data from human studies showed that ER $\beta$ is overexpressed in endometriotic lesions and may have a role in the pathophysiology. A high ER $\beta$-to-ER $\alpha$ ratio in endometriotic stromal cells is associated with suppressed PR and augmented COX-2 levels contributing to progesterone resistance and inflammation. ${ }^{100}$ High levels of ER $\beta$ result in suppressed ER $\alpha$ expression and estradiol responses in endometrial and endometriotic stromal cells. ${ }^{174}$ We have recently demonstrated increased ER $\alpha$ and $\operatorname{ER} \beta$ expression in ectopic and peritoneal tissue of patients with peritoneal endometriosis compared with control subjects, with a particularly marked elevation in ER $\beta$ observed, ${ }^{175}$ as has also been reported for ovarian endometriosis. ${ }^{164}$ The respective role of stromal and epithelial cells within lesions as well as the myeloid cells in the peritoneal cavity, and their immune and metabolic products, remains unclear. ER crosstalk and regulation is likely to be crucial. This complex area of biology necessitates further research and differences between murine models and the human pathology likely exist. Advances in understanding of the latter will necessitate standardized, well-designed studies and facilitate the discovery of relevant biomarker panels, which will hopefully serve to decrease the long delay before diagnosis. ${ }^{177-179}$

Estrogen production is also increased in endometriosis, ${ }^{180}$ likely influenced by the inflammatory environment. ${ }^{181}$ Here, the COX-2-derived eicosanoid $\mathrm{PGE}_{2}$, as a potent inducer of aromatase and Steroidogenic acute regulatory protein expression, has a pivotal role. ${ }^{182}$ Furthermore, estrogen degradation is regulated by progesterone and defective in progesterone resistance. ${ }^{183}$ Estrogen may be pro-inflammatory in endometriosis $^{184}$ and contributes to the pathophysiology of the disease as a mitogen causing aberrant proliferation ${ }^{185}$ and inhibition of apoptosis, ${ }^{186}$ decreasing the tumor-suppressor phosphatase and tensin homolog deleted on chromosome 10 via NF- $\kappa \mathrm{B}$ dependent pathways. ${ }^{187}$

Defective immunity and decreased production or activity of anti-inflammatory mediators such as $\mathrm{LXA}_{4}$ could account for the development of sustained inflammation seen in the reproductive tract and peritoneal fluid ${ }^{188}$ of endometriosis patients. Alterations in endometrial stroma have long been noted, ${ }^{173,189}$ including an exaggerated response to IL-1 $\beta$ and TNF- $\alpha$, resulting in excessive production of the inflammatory cytokines ENA-78 (epithelial neutrophil-activating peptide78), IL-6, and IL-8. ${ }^{190}$ Other inflammatory cytokines, including IL-17, increase IL- 8 secretion and expression of COX-2 ${ }^{191}$ and aromatase, ${ }^{192,193}$ making this pathway an attractive therapeutic target. ${ }^{194} \mathrm{LXA}_{4}$ production is induced by IL-13 in monocytes, ${ }^{30}$ and IL-13 is regulated during the menstrual cycle, with expression induced by ovarian steroid hormones and cytokines. ${ }^{39,195}$ Studies on micro(mi)RNA expression ${ }^{196,197}$ have revealed a wide variety of changes in this disease. Let-7 miRNA was one of those most upregulated in the endometrium of women with endometriosis ${ }^{196}$ and intruigingly, a let-7 miRNA polymorphism has been associated with endometriosis. ${ }^{198}$ Let-7 miRNAs inhibit IL-13 expression. ${ }^{199}$

Current treatments are directed toward surgical excision of ectopic endometrial tissue, and symptom alleviation, usually by targeting hormones or their receptors. Upon cessation of treatment, endometriosis frequently recurs. Furthermore, surgery can result in adhesion development, which can also lead to chronic pelvic pain and infertility. ${ }^{200}$ Novel approaches are therefore necessary as traditional therapies, the majority of which target hormones or their receptors, have been hampered by poor bioavailability, undesirable side effects, and a negative impact on fertility. ${ }^{201,202}$ As inflammation underlies the major endometriosis-associated symptoms, notably infertility and pain, a well-tolerated immunomodulatory therapy targeting inflammatory changes associated with this disease could improve symptoms without the untoward side-effects of existing treatments. As detailed above, $\mathrm{LXA}_{4}$ exerts a protective effect in preclinical endometriosis models, through antiinflammatory and anti-angiogenic mechanisms. ${ }^{120,121,159}$ 
Importantly, cycling remained unchanged, indicating that $\mathrm{LXA}_{4}$ does not alter ovarian function.

In conclusion, complex and interrelated pathways link the immune response to steroid hormone actions. Studies on endometrial function and endometriosis confirm the importance of the balance between inflammation and its resolution. Pregnancy itself is dependent on this compromise between self-defense and beneficence. ${ }^{110}$ Future research efforts will be needed to clarify the functional ramifications of $\mathrm{LXA}_{4}$ as an anti-inflammatory modulator and ER agonist. As a molecule with multiple modes of action and the ability to mitigate some E2-mediated responses, ${ }^{28}$ as well as potentially divergent actions on myeloid and non-myeloid cell types, revelations on its role in endometrial physiology and metabolism will likely identify therapeutic opportunities. Indeed, research in the emerging domain of immuno-metabolism is predicted to generate key insights into reproductive biology and disease.

\section{ACKNOWLEDGEMENTS}

Studies described here were funded by the Swiss National Science Foundation (grant number 310030-12076), Roche and Novartis Research Foundations as well as by the Department of Gynecology and Obstetrics, Centre Hospitalier Universitaire Vaudois (to GOC) and by the $\mathrm{NIH}$ R01HD067721 (to BAL).

\section{DISCLOSURE}

The authors declare no conflict of interest.

c 2013 Society for Mucosal Immunology

\section{REFERENCES}

1. Guerin, L.R., Prins, J.R. \& Robertson, S.A. Regulatory T-cells and immune tolerance in pregnancy: a new target for infertility treatment?. Hum. Reprod. Update 15, 517-535 (2009).

2. Evans, J. \& Salamonsen, L.A. Inflammation, leukocytes and menstruation. Rev. Endocr. Metab. Disord. 13, 277-288 (2012).

3. Jabbour, H.N., Sales, K.J., Catalano, R.D. \& Norman, J.E. Inflammatory pathways in female reproductive health and disease. Reproduction 138, 903-919 (2009).

4. Fierro, I.M., Kutok, J.L. \& Serhan, C.N. Novel lipid mediator regulators of endothelial cell proliferation and migration: aspirin-triggered-15R-lipoxin A(4) and lipoxin A(4). J. Pharmacol. Exp. Ther. 300, 385-392 (2002).

5. Gewirtz, A.T., Neish, A.S. \& Madara, J.L. Mechanisms of active intestinal inflammation and potential down-regulation via lipoxins. Adv. Exp. Med. Biol. 507, 229-236 (2002).

6. Kantarci, A. \& Van Dyke, T.E. Lipoxins in chronic inflammation. Crit. Rev. Oral Biol. Med. 14, 4-12 (2003).

7. Kowal-Bielecka, O., Kowal, K., Distler, O. \& Gay, S. Mechanisms of disease: leukotrienes and lipoxins in scleroderma lung disease-insights and potential therapeutic implications. Nat. Clin. Pract. Rheumatol. 3, 43-51 (2007)

8. Machado, F.S. \& Aliberti, J. Lipoxins as an immune-escape mechanism Adv. Exp. Med. Biol. 666, 78-87 (2009).

9. Bannenberg, G. \& Serhan, C.N. Specialized pro-resolving lipid mediators in the inflammatory response: an update. Biochim. Biophys. Acta. 1801, 1260-1273 (2010).

10. Macdonald, L.J., Boddy, S.C., Denison, F.C., Sales, K.J. \& Jabbour, H.N A role for lipoxin $\mathrm{A}(4)$ as an anti-inflammatory mediator in the human endometrium. Reproduction 142, 345-352 (2011).

11. Maldonado-Perez, D., Golightly, E., Denison, F.C., Jabbour, H.N. \& Norman, J.E. A role for lipoxin A4 as anti-inflammatory and proresolution mediator in human parturition. FASEB J. 25, 569-575 (2011).
12. Hedqvist, P., Raud, J., Palmertz, U., Haeggstrom, J., Nicolaou, K.C. \& Dahlen, S.E. Lipoxin A4 inhibits leukotriene B4-induced inflammation in the hamster cheek pouch. Acta. Physiol. Scand. 137, 571-572 (1989).

13. Lee, T.H., Lympany, P., Crea, A.E. \& Spur, B.W. Inhibition of leukotriene B4induced neutrophil migration by lipoxin A4: structure-function relationships. Biochem. Biophys. Res. Commun. 180, 1416-1421 (1991).

14. Badr, K.F., DeBoer, D.K., Schwartzberg, M. \& Serhan, C.N. Lipoxin A4 antagonizes cellular and in vivo actions of leukotriene D4 in rat glomerular mesangial cells: evidence for competition at a common receptor. Proc. Natl. Acad. Sci. USA 86, 3438-3442 (1989).

15. McMahon, B., Mitchell, D., Shattock, R., Martin, F., Brady, H.R. \& Godson, C. Lipoxin, leukotriene, and PDGF receptors cross-talk to regulate mesangial cell proliferation. FASEB J. 16, 1817-1819 (2002).

16. Celik, G.E., Erkekol, F.O., Misirligil, Z. \& Melli, M. Lipoxin A4 levels in asthma: relation with disease severity and aspirin sensitivity. Clin. Exp. Allergy 37, 1494-1501 (2007).

17. Merched, A.J., Ko, K., Gotlinger, K.H., Serhan, C.N. \& Chan, L. Atherosclerosis: evidence for impairment of resolution of vascular inflammation governed by specific lipid mediators. FASEB J. 22 3595-3606 (2008).

18. O'Meara, Y.M. \& Lipoxins, H.R. leukocyte recruitment and the resolution phase of acute glomerulonephritis. Kidney Int. Suppl. 58, S56-S61 (1997).

19. Vachier, I. et al. Severe asthma is associated with a loss of LX4, an endogenous anti-inflammatory compound. J. Allergy Clin. Immunol. 115, 55-60 (2005).

20. Marx, J.L. Cytokines are two-edged swords in disease. Science $\mathbf{2 3 9}$ 257-258 (1988)

21. Sala, A., Folco, G. \& Murphy, R.C. Transcellular biosynthesis of eicosanoids. Pharmacol. Rep. 62, 503-510 (2010).

22. Papayianni, A., Serhan, C.N., Phillips, M.L., Rennke, H.G. \& Brady, H.R. Transcellular biosynthesis of lipoxin A4 during adhesion of platelets and neutrophils in experimental immune complex glomerulonephritis. Kidney Int. 47, 1295-1302 (1995).

23. Serhan, C.N. Controlling the resolution of acute inflammation: a new genus of dual anti-inflammatory and proresolving mediators. J. Periodontol. 79, 1520-1526 (2008).

24. Brash, A.R., Boeglin, W.E. \& Chang, M.S. Discovery of a second 15Slipoxygenase in humans. Proc. Natl. Acad. Sci. USA 94, 6148-6152 (1997).

25. Claria, J. \& Serhan, C.N. Aspirin triggers previously undescribed bioactive eicosanoids by human endothelial cell-leukocyte interactions. Proc. Natl. Acad. Sci. USA 92, 9475-9479 (1995).

26. Birnbaum, Y. et al. Aspirin augments 15-epi-lipoxin A4 production by lipopolysaccharide, but blocks the pioglitazone and atorvastatin induction of 15-epi-lipoxin A4 in the rat heart. Prostaglandins Other Lipid Mediat. 83, 89-98 (2007).

27. Planaguma, A. et al. Lovastatin decreases acute mucosal inflammation via 15-epi-lipoxin A4. Mucosal Immunol. 3, 270-279 (2010).

28. Russell, R., Gori, I., Pellegrini, C., Kumar, R., Achtari, C. \& Canny, G.O. Lipoxin A4 is a novel estrogen receptor modulator. FASEB J. 25, 4326-4337 (2011).

29. Wecksler, A.T., Kenyon, V., Deschamps, J.D. \& Holman, T.R. Substrate specificity changes for human reticulocyte and epithelial 15-lipoxygenases reveal allosteric product regulation. Biochemistry 47, 7364-7375 (2008).

30. Nassar, G.M., Morrow, J.D., Roberts, L.J. 2nd, Lakkis, F.G. \& Badr, K.F. Induction of 15-lipoxygenase by interleukin-13 in human blood monocytes. J. Biol. Chem. 269, 27631-27634 (1994).

31. Bhattacharjee, A., Mulya, A., Pal, S., Roy, B., Feldman, G.M. \& Cathcart, M.K. Monocyte 15-lipoxygenase gene expression requires ERK1/2 MAPK activity. J. Immunol. 185, 5211-5224 (2010).

32. Yang, X.Y. et al. Interleukin (IL)-4 indirectly suppresses IL-2 production by human $\mathrm{T}$ lymphocytes via peroxisome proliferator-activated receptor gamma activated by macrophage-derived 12/15-lipoxygenase ligands. J. Biol. Chem. 277, 3973-3978 (2002).

33. Sica, A. \& Mantovani, A. Macrophage plasticity and polarization: in vivo veritas. J. Clin. Invest. 122, 787-795 (2012).

34. Li, Q., Cheon, Y.P., Kannan, A., Shanker, S., Bagchi, I.C. \& Bagchi, M.K. A novel pathway involving progesterone receptor, 12/15-lipoxygenasederived eicosanoids, and peroxisome proliferator-activated 
receptor gamma regulates implantation in mice. J. Biol. Chem. 279 11570-11581 (2004)

35. Wang, S.B., Hu, K.M., Seamon, K.J., Mani, V., Chen, Y. \& Gronert, K. Estrogen negatively regulates epithelial wound healing and protective lipid mediator circuits in the cornea. FASEB J. 26, 1506-1516 (2012).

36. Feng, Y., Bai, X., Yang, Q., Wu, H. \& Wang, D. Downregulation of 15lipoxygenase 2 by glucocorticoid receptor in prostate cancer cells. Int. J. Oncol. 36, 1541-1549 (2010).

37. Limor, R. et al. Aldosterone up-regulates 12- and 15-lipoxygenase expression and LDL oxidation in human vascular smooth muscle cells. J. Cell. Biochem. 108, 1203-1210 (2009).

38. Subbarayan, V. et al. 15-Lipoxygenase-2 gene regulation by its product 15-(S)-hydroxyeicosatetraenoic acid through a negative feedback mechanism that involves peroxisome proliferator-activated receptor gamma. Oncogene 25, 6015-6025 (2006).

39. Chegini, N., Ma, C., Roberts, M., Williams, R.S. \& Ripps, B.A. Differential expression of interleukins (IL) IL-13 and IL-15 throughout the menstrual cycle in endometrium of normal fertile women and women with recurrent spontaneous abortion. J. Reprod. Immunol. 56, 93-110 (2002).

40. Sato, K., Chisaka, H., Okamura, K. \& Challis, J.R. Effect of the interaction between lipoxygenase pathway and progesterone on the regulation of hydroxysteroid 11-Beta dehydrogenase 2 in cultured human term placental trophoblasts. Biol. Reprod. 78, 514-520 (2008).

41. Serhan, C.N., Chiang, N. \& Van Dyke, T.E. Resolving inflammation: dual anti-inflammatory and pro-resolution lipid mediators. Nat. Rev. Immunol. 8, 349-361 (2008).

42. Serhan, C.N. Resolution phase of inflammation: novel endogenous antiinflammatory and proresolving lipid mediators and pathways. Annu. Rev. Immunol. 25, 101-137 (2007).

43. Krishnamoorthy, S. et al. Resolvin D1 binds human phagocytes with evidence for proresolving receptors. Proc. Natl. Acad. Sci. USA 107 1660-1665 (2010).

44. Fiore, S., Romano, M., Reardon, E.M. \& Serhan, C.N. Induction of functional lipoxin A4 receptors in HL-60 cells. Blood 81, 3395-3403 (1993).

45. Fiore, S., Maddox, J.F., Perez, H.D. \& Serhan, C.N. Identification of a human cDNA encoding a functional high affinity lipoxin A4 receptor. J. Exp. Med. 180, 253-260 (1994).

46. Schaldach, C.M., Riby, J. \& Bjeldanes, L.F. Lipoxin A4: a new class of ligand for the Ah receptor. Biochemistry 38, 7594-7600 (1999).

47. Chiang, N. et al. The lipoxin receptor ALX: potent ligand-specific and stereoselective actions in vivo. Pharmacol. Rev. 58, 463-487 (2006).

48. Waechter, V. et al. Characterization of the promoter and the transcriptional regulation of the lipoxin A4 receptor (FPR2/ALX) gene in human monocytes and macrophages. J. Immunol. 188, 1856-1867 (2012).

49. Machado, F.S. et al. Anti-inflammatory actions of lipoxin A4 and aspirintriggered lipoxin are SOCS-2 dependent. Nat. Med. 12, 330-334 (2006).

50. Vondracek, J., Umannova, L. \& Machala, M. Interactions of the aryl hydrocarbon receptor with inflammatory mediators: beyond CYP1A regulation. Curr. Drug Metab. 12, 89-103 (2011).

51. Stockinger, B., Hirota, K., Duarte, J. \& Veldhoen, M. External influences on the immune system via activation of the aryl hydrocarbon receptor. Semin. Immunol. 23, 99-105 (2011).

52. Sanchez, Y. et al. The unexpected role for the aryl hydrocarbon receptor on susceptibility to experimental toxoplasmosis. J. Biomed. Biotechnol. 2010, 505694 (2010).

53. Stevens, E.A., Mezrich, J.D. \& Bradfield, C.A. The aryl hydrocarbon receptor: a perspective on potential roles in the immune system. Immunology 127, 299-311 (2009).

54. Igarashi, T. et al. Expression of Ah receptor and dioxin-related genes in human uterine endometrium in women with or without endometriosis. Endocr. J. 46, 765-772 (1999).

55. Kaijser, M., Granath, F., Jacobsen, G., Cnattingius, S. \& Ekbom, A. Maternal pregnancy estriol levels in relation to anamnestic and fetal anthropometric data. Epidemiology 11, 315-319 (2000).

56. Peter, M., Dorr, H.G. \& Sippell, W.G. Changes in the concentrations of dehydroepiandrosterone sulfate and estriol in maternal plasma during pregnancy: a longitudinal study in healthy women throughout gestation and at term. Horm. Res. 42, 278-281 (1994).

57. Clark, J.H. \& Markaverich, B.M. The agonistic and antagonistic actions of estriol. J. Steroid Biochem. 20, 1005-1013 (1984).
58. McDonnell, D.P. \& Norris, J.D. Connections and regulation of the human estrogen receptor. Science 296, 1642-1644 (2002).

59. Strauss, J.F. III \& Lessey, B.A. The structure, function, and evaluation of the female reproductive tract. In: (Strauss, J.F. III \& Barbieri, R.L., eds) Reproductive Endocrinology: Physiology, Pathophysiology, and Clinical Management. Saunders Elsevier; Philadelphia, PA, USA, 2009, 191-233.

60. Critchley, H.O. \& Saunders, P.T.K. Hormone receptor dyamics in a receptive human endometrium. Reprod. Sci. 16, 191-198 (2009).

61. Maybin, J.A., Critchley, H.O. \& Jabbour, H.N. Inflammatory pathways in endometrial disorders. Mol. Cell. Endocrinol. 335, 42-51 (2011).

62. King, A.E. \& Critchley, H.O. Oestrogen and progesterone regulation of inflammatory processes in the human endometrium. J. Steroid Biochem. Mol. Biol. 120, 116-126 (2010).

63. Burney, R.O. et al. Gene expression analysis of endometrium reveals progesterone resistance and candidate susceptibility genes in women with endometriosis. Endocrinology 148, 3814-3826 (2007).

64. Savaris, R.F. et al. Progesterone resistance in PCOS endometrium: a microarray analysis in clomiphene citrate-treated and artificial menstrual cycles. J. Clin. Endocrinol. Metab. 96, 1737-1746 (2011).

65. Burney, R.O. \& Giudice, L.C. Pathogenesis and pathophysiology of endometriosis. Fertil. Steril. 98, 511-519 (2012).

66. Young, S.L. \& Lessey, B.A. Progesterone function in human endometrium: clinical perspectives. Semin. Reprod. Med. 28, 5-16 (2010).

67. Straub, R.H. The complex role of estrogens in inflammation. Endocr. Rev. 28, 521-574 (2007).

68. Flickinger, G.L., Elsner, C., Illington, D.V., Muechler, E.K. \& Mikhail, G. Estrogen and progesterone receptors in the female genital tract of humans and monkeys. Ann. NY Acad. Sci. 286, 180 (1977).

69. Sanborn, B.M., Kuo, K.S. \& Held, B. Estrogen and progestogen binding site concentrations in human endometrium and cervix throughout the menstrual cycle and in tissue from women taking oral contraceptives. J. Steroid Biochem. 9, 951 (1978).

70. Brenner, R.M., West, N.B. \& McClellan, M.C. Esrogen and progestin receptors in the reproductive tract of male and female primates. Biol. Reprod. 42, 11-19 (1990).

71. Savouret, J.F. et al. The progesterone receptor. Biological effects of progestins and antiprogestins. Hum. Reprod. 9 (Suppl. 1), 7 (1994).

72. Bur, M.E., Greene, G.L. \& Press, M.F. Estrogen receptor localization in formalin-fixed, paraffin-embedded endometrium and endometriotic tissues. Int. J. Gynecol. Pathol. 6, 140 (1987).

73. Garcia, E. et al. Use of immunoctyochemistry of progesterone and estrogen receptors for endometrial dating. J. Clin. Endocrinol. Metab. 67 , 80 (1988).

74. Lessey, B.A., Killam, A.P., Metzger, D.A., Haney, A.F., Greene, G.L. \& McCarty, K.S. Jr. Immunohistochemical analysis of human uterine estrogen and progesterone receptors throughout the menstrual cycle. J. Clin. Endocrinol. Metab. 67, 334-340 (1988).

75. Masuzawa, H., Badokhon, N.H., Nakayama, K., Konishi, I., Nikaido, T. \& Fujii, S. Failure of down-regulation of estrogen receptors and progesterone receptors after medroxyprogesterone acetate administration for endometrial hyperplasias. Cancer 74, 2321 (1994).

76. Okulicz, W.C. \& Balsamo, M. A double immunofluorescent method for simultaneous analysis of progesterone-dependent changes in proliferation and the oestrogen receptor in endometrium of rhesus monkeys. J. Reprod. Fertil. 99, 545 (1993).

77. Slayden, O.D. \& Brenner, R.M. Hormonal regulation and localization of estrogen, progestin and androgen receptors in the endometrium of nonhuman primates: effects of progesterone receptor antagonists. Arch. Histol. Cytol. 67, 393-409 (2004).

78. Perrot-Applanat, M., Deng, M., Fernandez, H., Lelaidier, C., Meduri, G. \& Bouchard, P. Immunohistochemical localization of estradiol and progesterone receptors in human uterus throughout pregnancy: expression in endometrial blood vessels. J. Clin. Endocrinol. Metab. 78, 216 (1994).

79. Hou, Q., Paria, B.C., Mui, C., Dey, S.K. \& Gorski, J. Immunolocalization of estrogen receptor protein in the mouse blastocyst during normal and delayed implantation. Proc. Natl. Acad. Sci. USA 93, 2376 (1996).

80. Brenner, R.M., McClellan, M.C., West, N.B., Novy, M.J., Haluska, G.J. \& Sternfeld, M.D. Estrogen and progestin receptors in the macaque endometrium. Ann. NY Acad. Sci. 622, 149 (1991). 
81. Geisert, R.D., Brenner, R.M., Moffatt, R.J., Harney, J.P., Yellin, T. \& Bazer, F.W. Changes in oestrogen receptor protein, mRNA expression and localization in the endometrium of cyclic and pregnant gilts. Reprod. Fertil. Dev. 5, 247 (1993).

82. Slayden, O.D. \& Brenner, R.M. Hormonal regulation and localization of estrogen, progestin and androgen receptors in the endometrium of nonhuman primates: effects of progesterone receptor antagonists. Arch. Histol. Cytol. 67, 393-409 (2004).

83. Mead, R.A. \& Eroschenko, V.P. Changes in uterine estrogen and progesterone receptors during delayed implantation and early implantation in the spotted skunk. Biol. Reprod. 53, 827 (1995).

84. Das, N., Wang, J. \& Dey, S.K. Uterine preparation for implantation in the mouse is associated with coordinate expression of estrogen-responsive finger protein and estrogen receptor. Mol. Reprod. Dev. 46, 499 (1997).

85. Cherny, R.A., Salamonsen, L.A. \& Findlay, J.K. Immunocytochemical localization of oestrogen receptors in the endometrium of the ewe. Reprod. Fertil. Dev. 3, 321 (1991).

86. Aupperle, $\mathrm{H}$. et al. Cyclical endometrial steroid hormone receptor expression and proliferation intensity in the mare. Equine. Vet. J. 32, 228 (2000).

87. Lessey, B.A. \& Gorell, T.A. A cytoplasmic estradiol receptor in the immature beagle uterus. J. Steroid Biochem. Mol. Biol. 13, 211-217 (1980).

88. Lessey, B.A., Wahawisan, R. \& Gorell, T.A. Hormonal regulation of cytoplasmic estrogen and progesterone receptors in the beagle uterus and oviduct. Mol. Cell. Endocrinol. 21, 17180 (1981).

89. Lessey, B.A. et al. Endometrial progesterone receptors and markers of uterine receptivity in the window of implantation. Fertil. Steril. $65,477-483$ (1996).

90. de Ziegler, D., Frydman, R. \& Bouchard, P. Contribution of estrogen to the morphology of "secretory" endometrium?. Fertil. Steril. 63, 1135 (1995).

91. Lessey, B.A., Metzger, D.A., Haney, A.F. \& McCarty, K.S. Jr. Immunohistochemical analysis of estrogen and progesterone receptors in endometriosis: comparison with normal endometrium during the menstrual cycle and the effect of medical therapy. Fertil. Steril. 51, 409 (1989).

92. Bergqvist, A. \& Fernî, M. Oestrogen and progesterone receptors in endometriotic tissue and endometrium: comparison of different cycle phases and ages. Hum. Reprod. 8, 2211 (1993).

93. Nisolle, M., Casanas-Roux, F., Wyns, C., De Menten, Y., Mathieu, P.E. \& Donnez, J. Immunohistochemical analysis of estrogen and progesterone receptors in endometrium and peritoneal endometriosis: A new quantitative method. Fertil. Steril. 62, 751 (1994).

94. Matsuzaki, S., Fukaya, T., Uehara, S., Murakami, T., Sasano, H. \& Yajima, A. Characterization of messenger RNA expression of estrogen receptor- $\ddagger$ and -. in patients with ovarian endometriosis. Fertil. Steril. 73, 1219 (2000).

95. Lessey, B.A., Palomino, W.A., Apparao, K.B., Young, S.L. \& Lininger, R.A. Estrogen receptor-alpha (ER-alpha) and defects in uterine receptivity in women. Reprod. Biol. Endocrinol. 4 (Suppl. 1), S9 (2006).

96. O'Malley, B.W. A life-long search for the molecular pathways of steroid hormone action. Mol. Endocrinol. 19, 1402-1411 (2005).

97. Heldring, N. et al. Estrogen receptors: how do they signal and what are their targets. Physiol. Rev. 87, 905-931 (2007).

98. Couse, J.F. \& Korach, K.S. Contrasting phenotypes in reproductive tissues of female estrogen receptor null mice. Ann. NYAcad. Sci. 948, 1-8 (2001).

99. Krikun, G. et al. Endometrial endothelial cell steroid receptor expression and steroid effects on gene expression. J. Clin. Endocrinol. Metab. 90, 1812-1818 (2005).

100. Bulun, S.E. et al. Role of estrogen receptor-beta in endometriosis. Semin Reprod. Med. 30, 39-45 (2012).

101. Plante, B.J. et al. G protein-coupled estrogen receptor (GPER) expression in normal and abnormal endometrium. Reprod. Sci. 19, 684-693 (2012).

102. Korach, K.S. et al. Update on animal models developed for analyses of estrogen receptor biological activity. J. Steroid Biochem. Mol. Biol. 86 , 387-391 (2003).

103. Krege, J.H. et al. Generation and reproductive phenotypes of mice lacking estrogen receptor beta. Proc. Natl. Acad. Sci. USA 95, 15677-15682 (1998)

104. Otto, C. et al. GPR30 does not mediate estrogenic responses in reproductive organs in mice. Biol. Reprod. 80, 34-41 (2009).
105. Boonyaratanakornkit, V. \& Edwards, D.P. Receptor mechanisms of rapid extranuclear signalling initiated by steroid hormones. Essays Biochem. 40, 105-120 (2004)

106. Gori, I., Pellegrini, C., Staedler, D., Russell, R., Jan, C. \& Canny, G.O. Tumor necrosis factor-alpha activates estrogen signaling pathways in endometrial epithelial cells via estrogen receptor alpha. Mol. Cell. Endocrinol. 345, 27-37 (2011).

107. Hammes, S.R. \& Levin, E.R. Minireview: recent advances in extranuclear steroid receptor actions. Endocrinology 152, 4489-4495 (2011).

108. Salamonsen, L.A. \& Woolley, D.E. Menstruation: induction by matrix metalloproteinases and inflammatory cells. J. Reprod. Immunol. 44, 1-27 (1999).

109. Su, E.J. et al. Estrogen receptor-beta mediates cyclooxygenase-2 expression and vascular prostanoid levels in human placental villous endothelial cells. Am. J. Obstet. Gynecol. 200, 427. e1-8 (2009).

110. Warning, J.C., McCracken, S.A. \& Morris, J.M. A balancing act: mechanisms by which the fetus avoids rejection by the maternal immune system. Reproduction 141, 715-724 (2011).

111. Madak-Erdogan, Z. \& Katzenellenbogen, B.S. Aryl hydrocarbon receptor modulation of estrogen receptor alpha-mediated gene regulation by a multimeric chromatin complex involving the two receptors and the coregulator RIP140. Toxicol. Sci. 125, 401-411 (2012).

112. Brosens, J.J. \& Parker, M.G. Gene expression: oestrogen receptor hijacked. Nature 423, 487-488 (2003).

113. Thiruchelvam, U., Dransfield, I., Saunders, P.T. \& Critchley, H.O. The importance of the macrophage within the human endometrium. J. Leukoc. Biol. 93, 217-225 (2012).

114. Salamonsen, L.A. \& Woolley, D.E. Menstruation: induction by matrix metalloproteinases and inflammatory cells. J. Reprod. Immunol. 44, 1 (1999).

115. Henriet, P., Gaide Chevronnay, H.P. \& Marbaix, E. The endocrine and paracrine control of menstruation. Mol. Cell. Endocrinol. 358, 197-207 (2012).

116. McEwan, M., Lins, R.J., Munro, S.K., Vincent, Z.L., Ponnampalam, A.P. \& Mitchell, M.D. Cytokine regulation during the formation of the fetalmaternal interface: focus on cell-cell adhesion and remodelling of the extra-cellular matrix. Cytokine Growth Factor Rev. 20, 241-249 (2009).

117. Paule, S., Li, Y. \& Nie, G. Cytoskeletal remodelling proteins identified in fetal-maternal interface in pregnant women and rhesus monkeys. J. Mol. Histol. 42, 161-166 (2011).

118. Sodin-Semrl, S., Taddeo, B., Tseng, D., Varga, J. \& Fiore, S. Lipoxin A4 inhibits IL-1 beta-induced IL-6, IL-8, and matrix metalloproteinase-3 production in human synovial fibroblasts and enhances synthesis of tissue inhibitors of metalloproteinases. J. Immunol. 164, 2660-2666 (2000).

119. Wu, Y. etal. A lipoxin A4 analog ameliorates blood-brain barrier dysfunction and reduces MMP-9 expression in a rat model of focal cerebral ischemiareperfusion injury. J. Mol. Neurosci. 46, 483-491 (2012).

120. Chen, Q.H., Zhou, W.D., Pu, D.M., Huang, Q.S., Li, T. \& Chen, Q.X. 15Epi-lipoxin $A(4)$ inhibits the progression of endometriosis in a murine model. Fertil. Steril. 93, 1440-1447 (2010).

121. Xu, Z., Zhao, F., Lin, F., Chen, J. \& Huang, Y. Lipoxin A4 inhibits the development of endometriosis in mice: the role of anti-inflammation and anti-angiogenesis. Am. J. Reprod. Immunol. 67, 491-497 (2012).

122. Loke, Y.W., King, A. \& Burrows, T.D. Decidua in human implantation. Hum. Reprod. 10 (Suppl 2), 14-21 (1995).

123. Nagamatsu, T. \& Schust, D.J. The immunomodulatory roles of macrophages at the maternal-fetal interface. Reprod. Sci. 17, 209-218 (2010).

124. Ariel, A. \& Serhan, C.N. New lives given by cell death: macrophage differentiation following their encounter with apoptotic leukocytes during the resolution of inflammation. Front. Immunol. 3, 4 (2012).

125. Maderna, P. et al. FPR2/ALX receptor expression and internalization are critical for lipoxin A4 and annexin-derived peptide-stimulated phagocytosis. FASEB J. 24, 4240-4249 (2010).

126. Serhan, C.N. \& Savill, J. Resolution of inflammation: the beginning programs the end. Nat. Immunol. 6, 1191-1197 (2005).

127. Mathis, D. \& Shoelson, S.E. Immunometabolism: an emerging frontier. Nat. Rev. Immunol. 11, 81 (2011).

128. Ribas, V. et al. Myeloid-specific estrogen receptor alpha deficiency impairs metabolic homeostasis and accelerates atherosclerotic lesion development. Proc. Natl. Acad. Sci. USA 108, 16457-16462 (2011). 
129. Shapiro, H., Lutaty, A. \& Ariel, A. Macrophages, meta-inflammation, and immuno-metabolism. ScientificWorldJournal 11, 2509-2529 (2011).

130. Tsuji, I., Ami, K., Miyazaki, A., Hujinami, N. \& Hoshiai, H. Benefit of diagnostic laparoscopy for patients with unexplained infertility and normal hysterosalpingography findings. Tohoku J. Exp. Med. 219, 39-42 (2009).

131. Nakagawa, K., Ohgi, S., Horikawa, T., Kojima, R., Ito, M. \& Saito, H. Laparoscopy should be strongly considered for women with unexplained infertility. J. Obstet. Gynaecol. Res. 33, 665-670 (2007).

132. Sampson, J.A. Metastatic or embolic endometriosis, due to menstrual dissemination of endometrial tissue into venous circulation. Am. J. Pathol. 3, 93-110 (1927).

133. Gashaw, I., Hastings, J.M., Jackson, K.S., Winterhager, E. \& Fazleabas, A.T. Induced endometriosis in the baboon (Papio anubis) increases the expression of the proangiogenic factor CYR61 (CCN1) in eutopic and ectopic endometria. Biol. Reprod. 74, 1060-1066 (2006).

134. Hastings, J.M., Jackson, K.S., Mavrogianis, P.A. \& Fazleabas, A.T. The estrogen early response gene FOS is altered in a baboon model of endometriosis. Biol. Reprod. 75, 176-182 (2006).

135. D'Hooghe, T.M., Debrock, S., Hill, J.A. \& Meuleman, C. Endometriosis and subfertility: is the relationship resolved?. Semin. Reprod. Med. 21, 243-254 (2003).

136. Jackson, K.S., Brudney, A., Hastings, J.M., Mavrogianis, P.A., Kim, J.J. \& Fazleabas, A.T. The altered distribution of the steroid hormone receptors and the chaperone immunophilin FKBP52 in a baboon model of endometriosis is associated with progesterone resistance during the window of uterine receptivity. Reprod. Sci. 14, 137-150 (2007).

137. Wang, C., Mavrogianis, P.A. \& Fazleabas, A.T. Endometriosis is associated with progesterone resistance in the baboon (Papio anubis) oviduct: evidence based on the localization of oviductal glycoprotein 1 (OVGP1). Biol. Reprod. 80, 272-278 (2008).

138. Jasper, M.J., Tremellen, K.P. \& Robertson, S.A. Primary unexplained infertility is associated with reduced expression of the T-regulatory cell transcription factor Foxp3 in endometrial tissue. Mol. Hum. Reprod. 12, 301-308 (2006).

139. Robertson, S.A., Guerin, L.R., Moldenhauer, L.M. \& Hayball, J.D. Activating $T$ regulatory cells for tolerance in early pregnancy - the contribution of seminal fluid. J. Reprod. Immunol. 83, 109-116 (2009).

140. Bulun, S.E. Endometriosis. N. Engl. J. Med. 360, 268-279 (2009).

141. May, K. \& Becker, C.M. Endometriosis and angiogenesis. Minerva Ginecol. 60, 245-254 (2008).

142. Augoulea, A., Alexandrou, A., Creatsa, M., Vrachnis, N. \& Lambrinoudaki, I. Pathogenesis of endometriosis: the role of genetics, inflammation and oxidative stress. Arch. Gynecol. Obstet. 286, 99-103 (2012).

143. Salama, S.A. et al. Effect of tumor necrosis factor-\{alpha\} on estrogen metabolism and endometrial cells: potential physiological and pathological relevance. J. Clin. Endocrinol. Metab. 94, 285-293 (2009).

144. Chuang, P.C., Lin, Y.J., Wu, M.H., Wing, L.Y., Shoji, Y. \& Tsai, S.J. Inhibition of CD36-dependent phagocytosis by prostaglandin E2 contributes to the development of endometriosis. Am. J. Pathol. 176, 850-860 (2010).

145. Bacci, M. et al. Macrophages are alternatively activated in patients with endometriosis and required for growth and vascularization of lesions in a mouse model of disease. Am. J. Pathol. 175, 547-556 (2009).

146. Smith, K.A., Pearson, C.B., Hachey, A.M., Xia, D.L. \& Wachtman, L.M. Alternative activation of macrophages in rhesus macaques (Macaca mulatta) with endometriosis. Comp. Med. 62, 303-310 (2012).

147. Li, Y. et al. Pleiotropic regulation of macrophage polarization and tumorigenesis by formyl peptide receptor-2. Oncogene 30 , 3887-3899 (2011)

148. Carson, D.D. et al. Embryo implantation. Dev. Biol. 223, 217-237 (2000).

149. van Mourik, M.S., Macklon, N.S. \& Heijnen, C.J. Embryonic implantation: cytokines, adhesion molecules, and immune cells in establishing an implantation environment. J. Leukoc. Biol. 85, 4-19 (2009).

150. Donaghay, M. \& Lessey, B.A. Uterine receptivity: alterations associated with benign gynecological disease. Semin. Reprod. Med. 25, 461-475 (2007).

151. Montrone, M., Martorelli, D., Rosato, A. \& Dolcetti, R. Retinoids as critical modulators of immune functions: new therapeutic perspectives for old compounds. Endocr. Metab. Immune Disord. Drug Targets 9, 113-131 (2009).
152. Nagy, L., Szanto, A., Szatmari, I. \& Szeles, L. Nuclear hormone receptors enable macrophages and dendritic cells to sense their lipid environment and shape their immune response. Physiol. Rev. 92, 739-789 (2012).

153. Fazleabas, A.T., Donnelly, K.M., Mavrogianis, P.A. \& Verhage, H.G. Retinol-binding protein in the baboon ( Papio anubis ) uterus: Immunohistochemical characterization and gene expression. Biol. Reprod. 50, 1207 (1994).

154. Ito, K. et al. Retinoid receptors in the human endometrium and its disorders: a possible modulator of 17 beta-hydroxysteroid dehydrogenase. J. Clin. Endocrinol. Metab. 86, 2721-2727 (2001).

155. Lei, J., Hasegawa, H., Matsumoto, T. \& Yasukawa, M. Peroxisome proliferator-activated receptor alpha and gamma agonists together with TGF-beta convert human CD4 +CD25- T cells into functional Foxp3 + regulatory T cells. J. Immunol. 185, 7186-7198 (2010).

156. Klotz, L. et al. The nuclear receptor PPAR gamma selectively inhibits Th17 differentiation in a T cell-intrinsic fashion and suppresses CNS autoimmunity. J. Exp. Med. 206, 2079-2089 (2009).

157. Ye, Z.J. et al. Generation and differentiation of IL-17-producing CD4 + T cells in malignant pleural effusion. J. Immunol. 185, 63486354 (2010).

158. Motohashi, E. et al. Regulatory expression of lipoxin A4 receptor in physiologically estrus cycle and pathologically endometriosis. Biomed. Pharmacother. 59, 330-338 (2005).

159. Chen, Q., Zhou, W., Pu, D., Li, Z., Huang, Q. \& Chen, Q. The inhibitory effect of 15-R-LXA4 on experimental endometriosis. Eur. J. Obstet. Gynecol. Reprod. Biol. 145, 200-204 (2009).

160. Bruner-Tran, K.L., Eisenberg, E., Yeaman, G.R., Anderson, T.A., McBean, J. \& Osteen, K.G. Steroid and cytokine regulation of matrix metalloproteinase expression in endometriosis and the establishment of experimental endometriosis in nude mice. J. Clin. Endocrinol. Metab. 87, 4782-4791 (2002).

161. Walker, J. et al. Lipoxin a4 increases survival by decreasing systemic inflammation and bacterial load in sepsis. Shock 36, 410-416 (2011).

162. Wu, J. et al. Lipoxin A4 inhibits the production of proinflammatory cytokines induced by beta-amyloid in vitro and in vivo. Biochem. Biophys. Res. Commun. 408, 382-387 (2011).

163. Herington, J.L., Glore, D.R., Lucas, J.A., Osteen, K.G. \& Bruner-Tran, K.L. Dietary fish oil supplementation inhibits formation of endometriosisassociated adhesions in a chimeric mouse model. Fertil. Steril. 99, 543550 (2012).

164. Bulun, S.E. et al. Estrogen receptor-beta, estrogen receptor-alpha, and progesterone resistance in endometriosis. Semin. Reprod. Endocrinol. 28, 36-43 (2010).

165. Igarashi, T.M. et al. Reduced expression of progesterone receptor-B in the endometrium of women with endometriosis and in cocultures of endometrial cells exposed to 2,3,7,8-tetrachlorodibenzo-p-dioxin. Fertil. Steril. 84, 67-74 (2005).

166. Tan, H., Yi, L., Rote, N.S., Hurd, W.W. \& Mesiano, S. Progesterone receptor-a and -B have opposite effects on proinflammatory gene expression in human myometrial cells: implications for progesterone actions in human pregnancy and parturition. J. Clin. Endocrinol. Metab. 97, E719-E730 (2012).

167. Yang, H., Zhou, Y., Edelshain, B., Schatz, F., Lockwood, C.J. \& Taylor, H.S. FKBP4 is regulated by HOXA10 during decidualization and in endometriosis. Reproduction 143, 531-538 (2012).

168. Hirota, Y. et al. Deficiency of immunophilin FKBP52 promotes endometriosis. Am. J. Pathol. 173, 1747-1757 (2008).

169. Pavone, M.E., Reierstad, S., Sun, H., Milad, M., Bulun, S.E. \& Cheng, Y.H. Altered retinoid uptake and action contributes to cell survival in endometriosis. J. Clin. Endocrinol. Metab. 95, E300-E309 (2010).

170. Lee, J. et al. Differentially expressed genes implicated in unexplained recurrent spontaneous abortion. Int. J. Biochem. Cell Biol. 39, 2265-2277 (2007).

171. Wieser, F., Wu, J., Shen, Z., Taylor, R.N. \& Sidell, N. Retinoic acid suppresses growth of lesions, inhibits peritoneal cytokine secretion, and promotes macrophage differentiation in an immunocompetent mouse model of endometriosis. Fertil. Steril. 97, 1430-1437 (2012). 
172. Sawatsri, S., Desai, N., Rock, J.A. \& Sidell, N. Retinoic acid suppresses interleukin-6 production in human endometrial cells. Fertil. Steril. 73, 1012 (2009).

173. Tseng, J.F. et al. Interleukin-6 secretion in vitro is up-regulated ectopic and eutopic endometrial stromal cells from women with endometriosis. J. Clin. Endocrinol. Metab. 81, 1118 (1996).

174. Trukhacheva, E., Lin, Z., Reierstad, S., Cheng, Y.H., Milad, M. \& Bulun, S.E. ER\{beta\} regulates ER\{alpha\} expression in stromal cells derived from ovarian endometriosis. J. Clin. Endocrinol. Metab. 94, 615-622 (2008).

175. Pellegrini, C. et al. The expression of estrogen receptors as well as GREB1, C-MYC, and Cyclin D1, estrogen-regulated genes implicated in proliferation, is increased in peritoneal endometriosis. Fertil. Steril. 98, 1200-1208 (2012).

176. Burns, K.A., Rodriguez, K.F., Hewitt, S.C., Janardhan, K.S., Young, S.L. \& Korach, K.S. Role of estrogen receptor signaling required for endometriosis-like lesion establishment in a mouse model. Endocrinology 153, 3960-3971 (2012).

177. May, K.E., Conduit-Hulbert, S.A., Villar, J., Kirtley, S., Kennedy, S.H. \& Becker, C.M. Peripheral biomarkers of endometriosis: a systematic review. Hum. Reprod. Update 16, 651-674 (2010).

178. May, K.E., Villar, J., Kirtley, S., Kennedy, S.H. \& Becker, C.M. Endometrial alterations in endometriosis: a systematic review of putative biomarkers. Hum. Reprod. Update 17, 637-653 (2011).

179. Vodolazkaia, A. et al. Evaluation of a panel of 28 biomarkers for the noninvasive diagnosis of endometriosis. Hum. Reprod. 27, 2698-2711 (2012).

180. Noble, L.S., Simpson, E.R., Johns, A. \& Bulun, S.E. Aromatase expression in endometriosis. J. Clin. Endocrinol. Metab. 81, 174-179 (1996).

181. Bukulmez, O., Hardy, D.B., Carr, B.R., Word, R.A. \& Mendelson, C.R. Inflammatory status influences aromatase and steroid receptor expression in endometriosis. Endocrinology 149, 1190-1204 (2008).

182. Attar, E. et al. Prostaglandin E2 via steroidogenic factor-1 coordinately regulates transcription of steroidogenic genes necessary for estrogen synthesis in endometriosis. J. Clin. Endocrinol. Metab. 94, 623-631 (2009).

183. Bulun, S.E. et al. Progesterone resistance in endometriosis: link to failure to metabolize estradiol. Mol. Cell. Endocrinol. 248, 94-103 (2006).

184. Khoufache, K., Michaud, N., Harir, N., Kibangou Bondza, P. \& Akoum, A. Anomalies in the inflammatory response in endometriosis and possible consequences: a review. Minerva Endocrinol. 37, 75-92 (2012).

185. Park, J.S., Lee, J.H., Kim, M., Chang, H.J., Hwang, K.J. \& Chang, K.H. Endometrium from women with endometriosis shows increased proliferation activity. Fertil. Steril. 92, 1246-1249 (2009).

186. Critchley, H.O.D., Tong, S., Cameron, S.T., Drudy, T.A., Kelly, R.W. \& Baird, D.T. Regulation of bcl-2 gene family members in human endometrium by antiprogestin administration in vivo. J. Reprod. Fertil. 115, 389 (1999).

187. Zhang, H., Zhao, X., Liu, S., Li, J., Wen, Z. \& Li, M. 17 betaE2 promotes cell proliferation in endometriosis by decreasing PTEN via NFkappaBdependent pathway. Mol. Cell. Endocrinol. 317, 31-43 (2010).
188. Lousse, J.C., Van Langendonckt, A., Defrere, S., Ramos, R.G., Colette, S. \& Donnez, J. Peritoneal endometriosis is an inflammatory disease. Front Biosci (Elite Ed) 4, 23-40 (2012).

189. Hornung, D., Bentzien, F., Wallwiener, D., Kiesel, L. \& Taylor, R.N. Chemokine bioactivity of RANTES in endometriotic and normal endometrial stromal cells and peritoneal fluid. Mol. Hum. Reprod. 7, 163-168 (2001).

190. Bersinger, N.A., Gunthert, A.R., McKinnon, B., Johann, S. \& Mueller, M.D. Dose-response effect of interleukin (IL)-1beta, tumour necrosis factor (TNF)-alpha, and interferon-gamma on the in vitro production of epithelial neutrophil activating peptide-78 (ENA-78), IL-8, and IL-6 by human endometrial stromal cells. Arch. Gynecol. Obstet. 283, 1291-1296 (2011).

191. Hirata, T. et al. Interleukin-17F increases the secretion of interleukin-8 and the expression of cyclooxygenase 2 in endometriosis. Fertil. Steril. 96 , 113-117 (2011).

192. Ebert, A.D., Bartley, J. \& David, M. Aromatase inhibitors and cyclooxygenase-2 (COX-2) inhibitors in endometriosis: new questions-old answers?. Eur. J. Obstet. Gynecol. Reprod. Biol. 122, 144-150 (2005).

193. Attar, E. \& Bulun, S.E. Aromatase and other steroidogenic genes in endometriosis: translational aspects. Hum. Reprod. Update 12, 49-56 (2006).

194. Yamanaka, K. et al. Dienogest inhibits aromatase and cyclooxygenase-2 expression and prostaglandin $\mathrm{E}(2)$ production in human endometriotic stromal cells in spheroid culture. Fertil. Steril. 97, 477-482 (2012).

195. Roberts, M., Luo, X. \& Chegini, N. Differential regulation of interleukins IL-13 and IL- 15 by ovarian steroids, TNF-alpha and TGF-beta in human endometrial epithelial and stromal cells. Mol. Hum. Reprod. 11, 751-760 (2005).

196. Pan, Q., Luo, X., Toloubeydokhti, T. \& Chegini, N. The expression profile of micro-RNA in endometrium and endometriosis and the influence of ovarian steroids on their expression. Mol. Hum. Reprod. 13, 797-806 (2007).

197. Ohlsson Teague, E.M. et al. MicroRNA-regulated pathways associated with endometriosis. Mol. Endocrinol. 23, 265-275 (2009).

198. Grechukhina, O. et al. A polymorphism in a let-7 microRNA binding site of KRAS in women with endometriosis. EMBO Mol. Med. 4, 206-217 (2012).

199. Kumar, M. etal. Let-7 microRNA-mediated regulation of IL-13 and allergic airway inflammation. J. Allergy Clin. Immunol. 128, 1077-1085. e1-10 (2011).

200. Somigliana, E., Vigano, P., Benaglia, L., Busnelli, A., Vercellini, P. \& Fedele, L. Adhesion prevention in endometriosis: a neglected critical challenge. J. Minim. Invasive. Gynecol. 19, 415-421 (2012).

201. Vercellini, P., Somigliana, E., Vigano, P., Abbiati, A., Daguati, R. \& Crosignani, P.G. Endometriosis: current and future medical therapies. Best Pract. Res. Clin. Obstet. Gynaecol. 22, 275-306 (2008).

202. McDonnell, D.P. \& Wardell, S.E. The molecular mechanisms underlying the pharmacological actions of ER modulators: implications for new drug discovery in breast cancer. Curr. Opin. Pharmacol. 10, 620-628 (2010). 